\title{
Susceptibility, Oviposition Preference, and Biology of Grapholita molesta (Lepidoptera: Tortricidae) in Prunus Spp. Rootstock Genotypes
}

\author{
D. Bernardi, ${ }^{1,2}$ J. C. Lazzari, ${ }^{1}$ F. Andreazza, ${ }^{3}$ N. A. Mayer, ${ }^{1}$ M. Botton, ${ }^{4}$ and D. E. Nava ${ }^{1}$ \\ 'Laboratory of Entomology, Embrapa Clima Temperado, BR $392 \mathrm{Km}$ 78, Caixa Postal 403, Pelotas, RS 96010-971, Brazil \\ (dbernardi2004@yahoo.com.br; jose.cesarlazzari@hotmail.com; alex.mayer@embrapa.br; dori.edson-nava@embrapa.br), \\ ${ }^{2}$ Corresponding author, e-mail: dbernardi2004@yahoo.com.br, ${ }^{3}$ Department of Entomology, Federal University of Viçosa, Av. \\ Peter Henry Rolfs, s/n, Viçosa, MG 36570-900, Brazil (andreazzafelipe@yahoo.com.br), and ${ }^{4}$ Laboratory of Entomology, Embrapa \\ Uva e Vinho, Rua Livramento, 515 Caixa Postal 130, Bento Gonçalves, RS 95700-000, Brazil (marcos.botton@embrapa.br)
}

Subject Editor: Heather McAuslane

Received 14 March 2017; Editorial decision 31 June 2017

\begin{abstract}
Studying the susceptibility of peach trees to Grapholita molesta (Busck) is one of the major steps in the development of pest-resistant peach varieties. This work evaluated the susceptibility of 55 genotypes of the "Prunus Rootstock Collection" ("Coleção Porta-enxerto de Prunus") of Embrapa Temperate Climate (Pelotas, Rio Grande do Sul, Brazil) to the natural infestation of G. molesta, assessed the oviposition preference of G. molesta in choice and no-choice bioassays, and estimated the biological parameters and the fertility life table on different Prunus spp. genotypes in the laboratory. Genotypes Prunus kansuensis (Rehder), I-67-52-9, and I-67-52-4 were the most susceptible to G. molesta infestation in the field ( $>60 \%$ of branches infested), while 'Sharpe' (Prunus angustifolia $x$ Prunus spp.) and Prunus sellowii (Koehne) were the least infested ( $0 \%$ of branches infested). In choice and no-choice bioassays, G. molesta preferred to oviposit on $P$. kansuensis when compared with Sharpe. The Sharpe genotype also showed an antibiosis effect, resulting in negative effects on the fertility life table parameters when compared with the genotypes $P$. kansuensis and 'Capdeboscq.' The results found in the present study can provide information to initiate a long-term breeding program moving desired G. molesta resistance traits from the rootstock into the Prunus spp. cultivars.
\end{abstract}

Key words: Rosaceae, insect resistance, antibiosis, antixenosis, oriental fruit moth

In Brazil, 18,091 ha are cultivated with peach trees [Prunus persica (L.) Batsch]. The state of Rio Grande do Sul is the largest producer, cultivating 13,164ha of Prunus persica (Agrianual 2016). Commercially, the plants used to establish new orchards are produced by grafting scion cultivars onto peach seedling rootstock. The seedling rootstock material is mostly from peach pits discarded by the peach canning industry (Mayer et al. 2009, Mayer and Ueno 2012). This practice does not allow for identification and control of the genotype that is being used as the rootstock and promotes considerable unknown genetic diversity among the root systems of the plants, favoring the occurrence of peach tree short life (PTSL), a disease that compromises the roots and causes early plant death, reducing the useful life of the orchards (Mayer et al. 2009, Mayer and Ueno 2012).

As of 2007, Embrapa Temperate Climate (Pelotas, Rio Grande do Sul-RS, Brazil) resumed research with rootstocks of the genus Prunus spp. including different peach, nectarine, and plum tree species grown in the field, focusing mainly on tolerance to PTSL, which leads to sprouting collapse (Beckman et al. 2008; Mayer et al. 2009,
2013). However, during these studies, a lack of uniformity with respect to the level of infestation and sprouts damaged by oriental fruit moth larvae, Grapholita molesta (Busck) (Lepidoptera: Tortricidae), during feeding was observed. This species is considered one of the main pests of the peach tree in Brazil (Botton et al. 2011) and worldwide (Myers et al. 2007). This observation led to the hypothesis of the existence of genetic variability in terms of resistance factors (i.e., antixenosis [the insect does not chose the plant to oviposit] or antibiosis [the insect does oviposit, but their larvae have a reduced development or death]) associated with some Prunus spp. genotypes, owing to their different genetic composition (Smith 2005, Arge 2012), as observed in the United States for Synanthedon pictipes (Grote and Robinson) (Lepidoptera: Sesiidae) (Cottrell et al. 2011).

The use of resistant host plants is recommended in integrated pest management programs (Kogan 1998). However, owing to the high efficiency of chemical insecticides (Arioli et al. 2004, Chaves et al. 2014) or mating disruption (Pastori et al. 2012, Arioli et al. 2014), genetic improvement programs aimed at finding sources of peach resistance to G. molesta are scarce. The identification of 
potential sources of peach resistance to G. molesta would help in the definition of new management strategies in the field and in nurseries, leading to a reduction in the application of insecticide for the control of the species. Grapholita molesta infestations in peach seedling multiplication centers can be serious enough by fruit seedling production standards to result in nurseries closing (Castro 2010), and effective host-plant resistance could have significant implications for this industry. In this work, the following topics were evaluated: 1) the susceptibility of different Prunus spp. genotypes to natural infestation with G. molesta; 2) the oviposition preference of adults of G. molesta in choice and no-choice bioassays; and 3) the biology and fertility life tables of G. molesta in different Prunus spp. genotypes in the laboratory.

\section{Materials and Methods}

Susceptibility of Prunus Spp. Genotypes to G. molesta In total, 55 Prunus spp. genotypes from the "Prunus Rootstock Collection" ("Coleção de Porta-enxertos de Prunus") of Embrapa Temperate Climate, Pelotas, Rio Grande do Sul, Brazil (31 ${ }^{\circ}$ $40^{\prime} 41.61^{\prime \prime} \mathrm{S}, 52^{\circ} 27^{\prime} 03.32^{\prime \prime} \mathrm{W}$ ) were evaluated (Table 1). Seedlings of the different genotypes were planted during the year 2010 in an area of 6.0 by $2.0 \mathrm{~m}$ and were trained in a vase-shaped form. In July 2015, a drastic pruning was performed on the plants, cutting all major branches between 1.0 and $1.2 \mathrm{~m}$ above ground level, stimulating vigorous regrowth favorable to G. molesta infestation (Salles 1991, Botton et al. 2011). No pesticides were applied after pruning or during the evaluation period. Two visual evaluations of $G$. molesta infestation were performed on 20 branches per plant, with three different plants for each genotype during December 2015 and March 2016. Sprouts were considered infested by G. molesta larvae if they showed damaged apical meristems and the presence of tunnels and gum exudation (Salles 1991).

\section{Oviposition Preference of G. molesta on Prunus Spp. Genotypes}

Two genotypes were selected based on pest infestation in the field: 1) Prunus kansuensis Rehder (high infestation) and 2) 'Sharpe' (no infestation; Fig. 1). To verify the preference of G. molesta oviposition in these genotypes, choice and no-choice bioassays were performed in a greenhouse (temperature of $25 \pm 1{ }^{\circ} \mathrm{C}$, relative humidity $[\mathrm{RH}]$ of $60 \pm 10 \%$, and a photoperiod of 14:10 [L:D] h.

\section{Choice Bioassay}

Full branches of P. kansuensis and Sharpe that were $20 \mathrm{~cm}$ in length (containing eight leaves) were collected in the field and then individually placed in plastic cups $(180 \mathrm{ml})$ containing a $2 \%$ agar-water mixture in the greenhouse. The plastic cups were placed randomly and equidistant from each other in semitransparent plastic cages $(60.0 \mathrm{~cm}$ in length by $39.0 \mathrm{~cm}$ in width by $37.0 \mathrm{~cm}$ in height) to prevent contact between the leaves. Each cage contained two rectangular openings on the sides $(8.0 \mathrm{~cm}$ by $10.0 \mathrm{~cm})$ sealed with voile fabric to ensure ventilation. Ten 4-d-old mated G. molesta females obtained from laboratory rearing stocks on artificial diet (Arioli et al. 2007) were released into each cage. The adults were fed a $30 \%$ aqueous honey solution ad libitum supplied via capillary action using hydrophilic cotton placed in acrylic jars $(50 \mathrm{ml})$. The branches were replaced daily with new ones over a period of $5 \mathrm{~d}$. In the laboratory, the number of eggs present on the leaves and petioles was counted. The experimental design was a randomized block design with 10 replicates (cages), with each replicate composed of three branches from each genotype per cage, totaling 30 branches per treatment (P. kansuensis or Sharpe).

\section{No-Choice Bioassay}

The experiment was conducted in semitransparent plastic cages under the same conditions described for the choice bioassay. In each cage, five branches from each genotype (P. kansuensis or Sharpe treatments) were placed equidistant from each other. Subsequently, ten 4-d-old G. molesta mated females were released and fed an aqueous honey solution $(30 \%)$ supplied via capillary action using hydrophilic cotton. The branches were replaced daily with new branches until the females died, and the eggs were counted. The experimental design was a randomized block design with six replicates (cages) per treatment, each replicate consisting of five branches of each genotype, totaling 30 branches per treatment (P. kansuensis or Sharpe).

\section{Biology of G. molesta in Prunus Spp. Genotypes}

Three genotypes (treatments) were used: P. kansuensis (high infestation $[69.2 \pm 3.0 \%]$ ), 'Capdeboscq' (medium infestation [40.8 \pm $2.7 \%]$ ), and Sharpe (no infestation [0\%]; Fig. 1), which were individually placed in cages made from plastic cups $(180 \mathrm{ml})$ containing a $2 \%$ agar-water mixture. Subsequently, one G. molesta larva up to $24 \mathrm{~h}$ in age was transferred per branch with the aid of a fine-tipped brush. At the end of the larval development, a piece of hydrophilic cotton was placed inside the cage to serve as a pupation site. To avoid escape of the larvae, another plastic cup $(100 \mathrm{ml})$ was placed in the top of each cage in an inverted position, according to Chaves et al. (2014). The experimental design was a completely randomized design with 100 replicates (larvae) per treatment. The biological parameters evaluated were as follows: 1) duration (days) and viability (\%) of larval and pupal stages and adult longevity; 2) fecundity of G. molesta females and the viability and duration of the embryonic period of the eggs of these females; 3) duration of the oviposition period; 4) sex ratio; and 5) weight of 24-h-old pupae. The duration and viability of the different stages of development were determined through daily observations. The longevity and fecundity were evaluated through observation of 15 mating pairs from each treatment individually placed in cages made from plastic cups $(180 \mathrm{ml}$; oviposition substrate) inverted on a petri dish $(1 \mathrm{~cm}$ in height by $9 \mathrm{~cm}$ in diameter). The adult were fed a $30 \%$ aqueous honey solution ad libitum provided by capillary action using hydrophilic cotton placed in glass tubes $(10 \mathrm{ml})$. The number of eggs and adult mortality were recorded daily. The viability and the duration of the embryonic period were obtained from the second laying of each couple. Egg laying was observed daily to determine the duration of the embryonic period and viability.

\section{Statistical Analyses}

For the evaluation of the natural infestation in the field, the experimental design used was a completely randomized design, with 55 treatments (genotypes) and three replicates of one plant each. Because the data conformed to a binomial distribution, they were subjected to nonlinear regression analysis (PROC GENMOD, SAS Institute 2000), with a logit link function to estimate the mean infestation values (\%) for each genotype and their respective $95 \%$ confidence intervals. In addition, after testing the data residuals for normality by the Shapiro-Wilk test and for homoscedasticity by Hartley's and Bartlett's tests (PROC GLM, SAS Institute 2000), a clustering analysis of homogeneous means was performed by the 
Table 1. Identification, species, and origin of genotypes at "Prunus Rootstock Collection" of the Embrapa Clima Temperado, 2016

\begin{tabular}{|c|c|c|}
\hline Genotype & Species $^{\mathrm{a}}$ & Origin $^{\mathrm{b}}$ \\
\hline $\mathrm{I}-67-52-4$ & P. persica & United States \\
\hline I-67-52-9 & P. persica & United States \\
\hline I- $67-53-5$ & P. persica & United States \\
\hline I-67-54-12 & P. persica & United States \\
\hline I-67-55-9 & P. persica & United States \\
\hline I-67-55-13 & P. persica & United States \\
\hline I-67-57-14 & P. persica & United States \\
\hline I-93-21 & P. persica & United States \\
\hline I-93-27 & P. persica & United States \\
\hline I-93-30 & P. persica & United States \\
\hline I-93-37 & P. persica & United States \\
\hline I-93-38 & P. persica & United States \\
\hline 'Barrier' & P. persica $\times$ P. davidiana & Italy \\
\hline 'Cadaman' & P. persica $\times$ P. davidiana & France \\
\hline 'GF 677' & P. persica $\times$ P. amygdalus & France \\
\hline G $x$ N.9 & P. persica $\times$ P. dulcis & Unknown \\
\hline 'Ishtara' & (P. cerasifera $\times P$. salicina) $\times(P$. cerasifera $\times P$. persica $)$ & France \\
\hline 'Julior' & P. insititia $x$ P. domestica & France \\
\hline 'Marianna 2624' & P. cerasifera $\times P$. munsoniana & California, United States \\
\hline 'Myrabolan 29C' & P. cerasifera & Unknown \\
\hline Tardio - 01 & P. persica & Grower from Pelotas-RS/Brazil \\
\hline 'Aldrighi' CPACT & P. persica & GB of Embrapa Clima Temperado \\
\hline Capdeboscq & P. persica & GB of Embrapa Clima Temperado \\
\hline 'Genovesa' & P. salicina & GB of Embrapa Clima Temperado \\
\hline 'De Guia' & P. persica & GB of Embrapa Clima Temperado \\
\hline 'Rosaflor' & P. persica & GB Embrapa Clima Temperado \\
\hline Prunus mandchurica & P. mandschurica & GB of Embrapa Clima Temperado \\
\hline 'Tsukuba-2' CPACT & P. persica & GB of Embrapa Clima Temperado \\
\hline México Fila 1 & P. persica & Mexico \\
\hline México Fila 2 & P. persica & Mexico \\
\hline 'Santa Rosa' & P. salicina & California, United States \\
\hline 'Piazito' & P. persica & GB Embrapa Clima Temperado \\
\hline 'Tsukuba-01' & P. persica & Japan \\
\hline 'Tsukuba-02' & P. persica & Japan \\
\hline 'Tsukuba-03' & P. persica & Japan \\
\hline 'Okinawa' & P. persica & Florida, United States \\
\hline 'Flordaguard' & 'Chico $11^{\prime} \times$ P. davidiana & Florida, United States \\
\hline Cereja Precoce & Prunus sp. & São Joaquim—SC/Brazil \\
\hline Cereja Tardia & Prunus sp. & São Joaquim—SC/Brazil \\
\hline Pinheiro Preto & P. persica & Pinheiro Preto-SC/Brazil \\
\hline 'Nemared' & P. persica & California, United States \\
\hline Prunus sellowii & P. sellowii & Pelotas-RS/Brazil \\
\hline Prunus kansuensis & P. kansuensis & GB of Embrapa Clima Temperado \\
\hline Prunus persica & P. persica & GB of Embrapa Clima Temperado \\
\hline Cons. 594 & P. persica & GB of Embrapa Clima Temperado \\
\hline Casc. 1005 & P. persica & GB of Embrapa Clima Temperado \\
\hline 'Bolinha' & P. persica & GB of Embrapa Clima Temperado \\
\hline 'Farrapos' & P. persica & GB of Embrapa Clima Temperado \\
\hline Chorão 2003-229-03 & P. persica & GB of Embrapa Clima Temperado \\
\hline 'Turquesa' & P. persica & GB of Embrapa Clima Temperado \\
\hline 'Aldrighi' & P. persica & Grower from Pelotas—RS/Brazil \\
\hline 'Maracotão' & P. persica & Grower from Pelotas-RS/Brazil \\
\hline 'Rigitano' & P. mume & FCAV/UNESP, Jaboticabal—SP/Brazil \\
\hline Clone 15 & P. mume & FCAV/UNESP, Jaboticabal_SP/Brazil \\
\hline Sharpe & Chickasaw $($ P. angustifolia) $x$ Prunus spp. & Florida, United States \\
\hline
\end{tabular}

\footnotetext{
${ }^{a}$ P._-Prunus.

${ }^{b} \mathrm{~GB}$-live germplasm bank.
}

Scott-Knott test $(P \leq 0.05)$ using the software Assistat v.7.7 (Silva and de Azevedo 2016).

For the choice and no-choice bioassays, the experimental design was a randomized block with 10 and 6 replicates per treatment (genotypes), respectively. Data residuals from the number of eggs per branch were tested for normality by the Shapiro-Wilk test and for homoscedasticity by Hartley's and Bartlett's tests. Subsequently, they were subjected to analysis of variance (ANOVA), and the means were compared by Tukey's test at a 5\% significance level $(P \leq 0.05 ;$ PROC UNIVARIATE, SAS Institute 2000). 


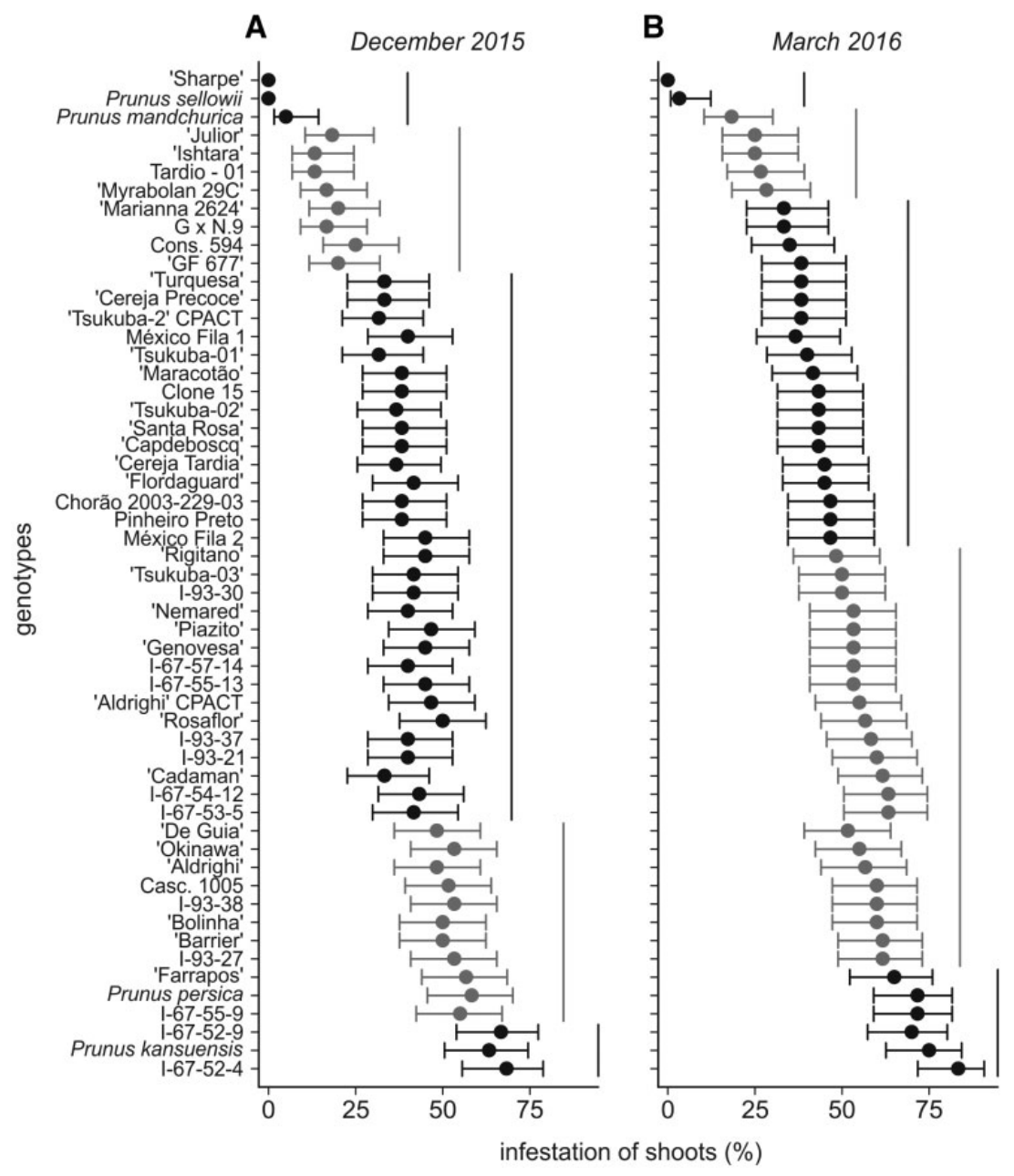

Fig. 1. Natural infestation (\%) of G. molesta in different Prunus spp. genotypes at field. (A) December, 2015 and (B) March, 2016. Note: Error bars represent the $95 \%$ confidence interval of the regression analysis. The genotypes grouped by the same vertical bar diagrams form homogeneous groups of susceptibility, according to the Scott-Knott test $(P \leq 0.05)$.

The data on the duration of the egg, larval, and pupal stages and the egg-adult period, pupal weight, female and male longevity, and daily fecundity were transformed into $(x+0.5)^{-0.5}$, and significant differences between the treatments were determined using the least squares means at a significance level of $P \leq 0.05$ (PROC GLM, SAS Institute 2000). The possible deviation in the sex ratio was tested by the chi-squared test $\left(\chi^{2} ; P \leq 0.05\right.$; PROC FREQ, SAS Institute 2000). In addition, the fertility life table was calculated by estimating the interval between generations, the net reproduction rate, the intrinsic growth rate, and the finite growth rate. The parameters of the fertility life table and their standard errors were estimated using the "Lifetable.sas" program (Maia et al. 2000), and the means were compared by a two-tailed $t$ test $(P \leq 0.05$; PROC MEANS, SAS Institute 2000).

\section{Results}

\section{Susceptibility and Oviposition Preference of G. molesta in Prunus Spp. Genotypes}

Through clustering analysis, significant differences were observed in the infestation of G. molesta in the 55 genotypes evaluated, with the percentage of infested branches varying from $0 \%$ to $70 \%$ during the two evaluation periods (December 2015 and March 2016; Fig. 1). The genotypes $P$. kansuensis, I-67-52-9, and I-67-52-4 presented the largest natural infestations of G. molesta in the two evaluations performed (Fig. 1). The lowest infestations were observed for Sharpe and Prunus sellowii Koehn, in both cases with statistically significant differences $(P \leq 0.05)$ from the other genotypes evaluated (Fig. 1). Most of the evaluated genotypes $(72 \%$ of the total) presented mean infestations between $30 \%$ and $60 \%$ (Fig. 1).

In the choice bioassay, a greater preference of G. molesta oviposition in $P$. kansuensis was observed, with a significantly higher number of eggs $(F=2.29$; df $=1,140 ; P<0.0001)$ than Sharpe (Fig. 2). Similarly, in the no-choice bioassay, there was a greater number of eggs deposited in $P$. kansuensis $(F=1.14 ; \mathrm{df}=1,140 ; P<0.0001)$.

\section{Fertility Life Table of G. molesta in Prunus Spp. Genotypes}

There was no significant difference in egg $(F=0.954 ; \mathrm{df}=2,74$; $P=0.8702)$ or pupal $(F=8.54 ; \mathrm{df}=2,80 ; P=0.7526)$ stage duration for G. molesta. However, larvae fed the Sharpe genotype showed a larval stage extension of $3 \mathrm{~d}(F=17.05 ; \mathrm{df}=2,74$; $P<0.0001)$ compared with larvae that fed on $P$. kansuensis or Capdeboscq (Fig. 3A). The viability of the egg $(F=9.47 ; \mathrm{df}=2,74$; $P=0.3017)$ and pupal $(F=1.24 ; \mathrm{df}=2,80 ; P=0.1256)$ stages did not differ between the treatments; however, larval viability was significantly lower $(F=9.47 ; \mathrm{df}=2,74 ; P<0.0001)$ in the Sharpe rootstock $(32 \%)$ than in $P$. kansuensis $(69 \%)$ and Capdeboscq 


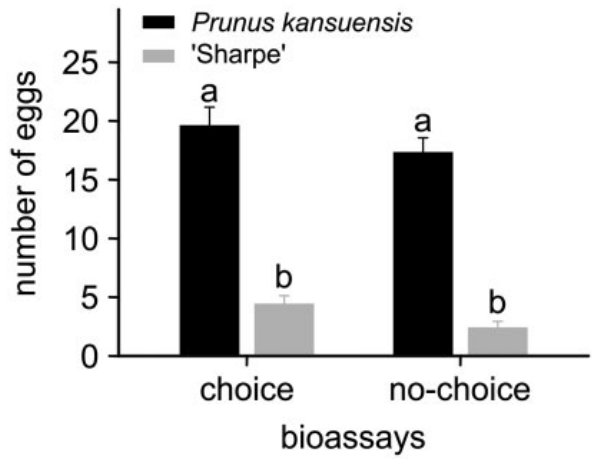

Fig. 2. Number of eggs of $G$. molesta (mean \pm SE) per shoot in choice and no-choice bioassays. Note: Different letters indicate significant differences between bars within each bioassay type, according to the Tukey test $(P \leq 0.05)$.

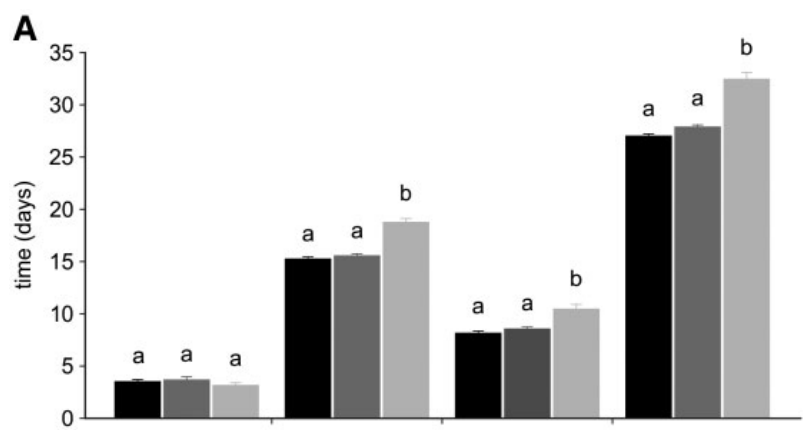

B

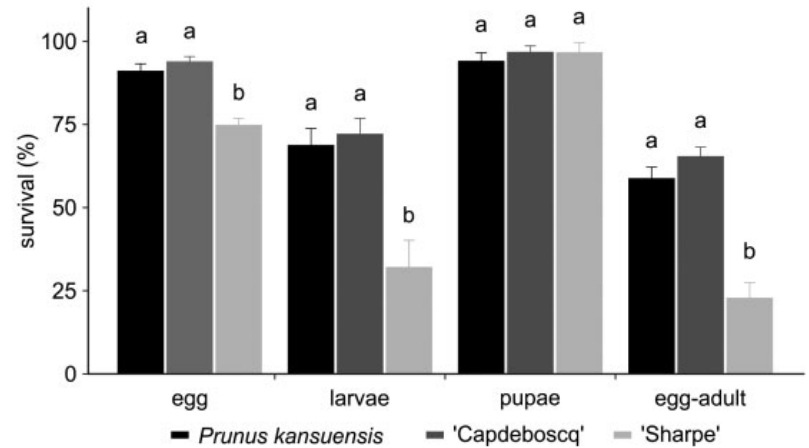

Fig. 3. Time (days) (A) and viability (\%) (B) (mean \pm SE) of the developmental stages of G. molesta fed on different Prunus spp. genotypes. Note: Different letters indicate significant differences between the bars within each developmental stage, according to the Tukey test $(P \leq 0.05)$.

(72\%; Fig. 3B). The reduction in larval viability caused by the Sharpe genotype negatively impacted the viability of the egg-adult period, in which only $23 \%$ of the insects completed the biological cycle, differing significantly from $P$. kansuensis and Capdeboscq (Fig. 3B).

There was also a significant reduction $(F=9.47 ; \mathrm{df}=2,74$; $P<0.0001)$ in pupal weight when the larvae fed on Sharpe rootstock $\quad(0.0086 \pm 0.003 \mathrm{~g})$ compared with $P$. kansuensis $(0.0127 \pm 0.011 \mathrm{~g})$ and Capdeboscq $(0.0120 \pm 0.008 \mathrm{~g})$. However, feeding on the different genotypes during the larval stage did not cause significant differences between the proportions of females in the sample group of each treatment $\left(\chi^{2}=18.78 ; \mathrm{df}=2,74\right.$; $P=0.2802$; Table 2).

The development of the immature phase of G. molesta in the Sharpe genotype generated lower values of longevity in females
$(F=2.09 ; \mathrm{df}=2,74 ; P=0.0012)$, males $(F=3.91 ; \mathrm{df}=2,74 ;$ $P=0.0006)$, and in the oviposition period $(F=4.39 ; \mathrm{df}=2,32$; $P=0.0028$ ) than in P. kansuensis and Capdeboscq (Table 2). In addition, female adults fed Sharpe when in the larval stage showed lower reproductive performance, with a reduction of $\sim 60 \%$ in the mean daily fecundity $(F=1.91 ; \mathrm{df}=2,32 ; P<0.0001)$ compared with P. kansuensis and Capdeboscq (Table 2). This reduction negatively affected the fertility life table parameters of the insects that developed in the Sharpe rootstock. The mean interval between generations differed significantly $(P \leq 0.05)$ between the genotypes studied (Table 2). The net reproductive rate values indicated a reduction of around $81.7 \%$ in females' ability to generate new females, when insects fed on Sharpe branches. Based on these results, after $\sim 35 \mathrm{~d}$ of development, 973.70 and 791.90 females resulting from each breeding female in $P$. kansuensis and Capdeboscq were expected, respectively (Table 2). For Sharpe, only 1.08 new females were expected. Similarly, insects feeding on Sharpe branches had a lower intrinsic growth rate with a population reduction of $>90 \%$ compared with $P$. kansuensis and Capdeboscq and a smaller finite rate of daily population increase (Table 2).

\section{Discussion}

Knowledge of the biological development of a species is a fundamental strategy for the successful management and control of pest arthropods in the field (Kogan 1998). Based on the months with a higher occurrence (December and March) of G. molesta in peach orchards in Brazil (Salles and Marini 1989, Botton et al. 2001), differences were observed in the susceptibility and preference of natural infestation of G. molesta in the field in the 55 rootstock genotypes of the genus Prunus evaluated in this study. The observed nonpreference for part of the evaluated genotypes, or the discrimination of the pest by its hosts, occurs after the insect lands on the substrate (Edwards and Wratten 1981). This choice is the exact moment that the insect performs an identification of the nutritional and chemical qualities of the plant to colonize it and increase the probability of survival of its offspring (Edwards and Wratten 1981, Myers et al. 2006).

The greater preference of natural infestation of $G$. molesta for the genotypes $P$. kansuensis, I-67-52-9, and I-67-52-4 may be associated with the narrow genetic base of these materials (Arge 2012) because $P$. kansuensis is a species of wild peach but is morphologically similar to the cultivated peach Prunus persica (Cao et al. 2011), considered an ideal host species for the development of G. molesta (Silva et al. 2010, Chaves et al. 2014). This fact is reinforced by the low infestation observed in the Sharpe genotype, which is supposed to be a natural hybrid between the 'Chickasaw' plum [Prunus angustifolia (Marsh.)] and an unknown species of plum (Beckman et al. 2008). In an oviposition preference bioassay, it was observed that Sharpe presented the smallest number of eggs per branch, both in choice bioassays and by demonstrating a lower preference for oviposition in these structures. These results are in line with the field evaluations, in which no pest infestation was observed in the Sharpe rootstock, similar to the results observed for S. pictipes in branches of this material (Cottrell et al. 2011).

Because G. molesta larvae have low mobility, the choice of the ideal branch for adult oviposition and later feeding of the larvae is of paramount importance for the survival of the population (Myers et al. 2006). Therefore, P. kansuensis, which was the most infested genotype in the field and was preferred for greenhouse oviposition, was shown to be an adequate food source for the biological development of the insect when compared with Sharpe, similar to the results 
Table 2. Biological parameters of G. molesta in Prunus spp. genotypes

\begin{tabular}{|c|c|c|c|}
\hline Biological parameter & Prunus kansuensis & Capdeboscq & Sharpe \\
\hline \multicolumn{4}{|l|}{ Adult parameters ${ }^{\mathrm{a}}$} \\
\hline Sex ratio $(+/ q+\hat{\jmath})$ & $0.52^{n s}$ & $0.54^{n s}$ & $0.50^{n s}$ \\
\hline Female longevity (d) & $13.5 \pm 0.3 \mathrm{a}$ & $13.2 \pm 0.2 \mathrm{a}$ & $5.0 \pm 1.3 b$ \\
\hline Male longevity (d) & $14.0 \pm 0.25 a$ & $13.6 \pm 0.21 \mathrm{a}$ & $5.6 \pm 0.67 b$ \\
\hline Oviposition (d) & $9.1 \pm 0.2 \mathrm{a}$ & $9.5 \pm 0.1 \mathrm{a}$ & $4.4 \pm 0.4 b$ \\
\hline Eggs/female/d & $41.6 \pm 1.4 \mathrm{a}$ & $39.8 \pm 1.2 \mathrm{a}$ & $13.3 \pm 1.7 \mathrm{~b}$ \\
\hline \multicolumn{4}{|c|}{ Fertility life table parameters ${ }^{\mathrm{b}}$} \\
\hline$T(\mathrm{~d})$ & $35.6 \pm 0.11 \mathrm{a}$ & $34.8 \pm 0.16 \mathrm{a}$ & $41.2 \pm 1.25 b$ \\
\hline$R_{o}$ (아/우) & $740.15 \pm 32.6 \mathrm{a}$ & $639.15 \pm 29.3 \mathrm{a}$ & $134.9 \pm 11.3 b$ \\
\hline$r_{m}(+/ 9 / \mathrm{d})$ & $0.158 \pm 0.001 \mathrm{a}$ & $0.167 \pm 0.002 \mathrm{a}$ & $0.012 \pm 0.001 b$ \\
\hline$\lambda$ & $1.248 \pm 0.002 \mathrm{a}$ & $1.239 \pm 0.001 \mathrm{a}$ & $0.008 \pm 0.001 \mathrm{~b}$ \\
\hline
\end{tabular}

${ }^{a}$ Means $( \pm$ SE) followed by the same letter in a line are not significantly different (LS MEANS with Tukey's adjustment; $P<0.05$ ); $n s-$ not significant.

${ }^{b} T$-mean length of a generation; $R_{o}$-net reproductive rate; $r_{m}$-intrinsic rate of population increase; $\lambda$-finite rate of population increase.

observed for the lesser peachtree borer S. pictipes (Cottrell et al. 2008). Several studies have demonstrated that the source of food may influence the biological parameters of G. molesta (Myers et al. 2006, 2007; Joshi et al. 2007, 2015; Silva et al. 2010; Chaves et al. 2014). The lower oviposition preference for Sharpe may be associated with the presence of chemical compounds released by the leaves, the presence of physical barriers (such as hairs or glandular trichomes), and the shape of the leaves that provide an antixenotic or nonpreference effect for oviposition and infestation in the field (Lara 1991, Straub 2003, Al Bitar et al. 2014, Joshi et al. 2015).

In analyzing the biological parameters and the development capacity of G. molesta in the laboratory, the Sharpe genotype provided an increase and a reduction in the larval and pupal viability of $G$. molesta compared with P. kansuensis and Capdeboscq. These results suggest that the Sharpe rootstock, in addition to having an antixenotic effect on the pest, also presents antibiotic substances that affect the survival of G. molesta larvae, leading to a greater larval stunting (Bottger and Patana 1966). According to the fertility life table, which permits evaluations of the performance of a species on a diet or in the host, for all parameters, Sharpe branches provided values lower than the values produced by $P$. kansuensis and Capdeboscq. It can be observed that Sharpe presents nutritional mechanisms that contribute to a reduced insect growth rate in addition to the presence of a deterrent factor or the absence of a stimulant for feeding. In turn, $P$. kansuensis and Capdeboscq were shown to be ideal hosts for the highest population growth of G. molesta.

Because Sharpe is considered promising for the management of PTSL, increasing orchard viability (Beckman et al. 2008, Mayer et al. 2013), the use of this cultivar in peach seedling multiplication centers will assist in choosing the best management strategy for the oriental fruit moth in those multiplication centers. This will lead to less use of chemical insecticides and, consequently, less environmental contamination in these specific areas (Castro, 2010). However, it is important to note that currently, outside the seedling centers, Sharpe is present only as a rootstock. Because the roots are not a target of this pest species, no benefits regarding G. molesta management should be expected by its use. Nevertheless, it can be a primary source of genes for breeding programs to develop resistant scion cultivars.

Thus, considering the scarcity of resistance information for Prunus spp. to G. molesta, the results obtained in this work constitute an important step in the search for information regarding potential sources for the isolation of resistance in plants that can provide adverse effects on the preference and development of $G$. molesta. The information obtained will help in determining the focus of new genetic improvement programs of Prunus spp. and in the search for genes of interest that are responsible for negatively influencing the bioecological behavior of the pest.

\section{References Cited}

Agrianual. 2016. Pêssego. FNP Consultoria \& Comercio, São Paulo, Brazil. Al Bitar, L., S. N. Gorb, C.P.W. Zebitz, and D. Voigt. 2014. Egg adhesion of the codling moth Cydia pomonella L. (Lepidoptera, Tortricidae) to various substrates: II. Fruit surfaces of different apple cultivars. Arthropod-Plant Interact. 8: 57-77.

Arge, L.W.P. 2012. Diversidade, estrutura e relação genética de portaenxertos de Prunus avaliados pela análise de caracteres morfológicos e de loci SSR. M.S. Dissertation, Universidade Federal de Pelotas.

Arioli, C., F. Molinari, M. Botton, and M. Garcia. 2007. Técnica de criação de Grapholita molesta (Busck, 1916) (Lepidoptera: Tortricidae) em laboratório utilizando dieta artificial para a produção de insetos visando estudos de comportamento e controle. Boletim De Pesquisa e Desenvolvimento/ Embrapa Uva e Vinho 13: 14.

Arioli, C. J., M. Botton, and G. A. Carvalho. 2004. Controle químico da Grapholita molesta (Busck) (Lepidoptera: Tortricidae) na cultura do pessegueiro. Ciência Rural 34: 1695-1700.

Arioli, C. J., P. L. Pastori, M. Botton, M. S. Garcia, R. Borges, and A. MafraNeto. 2014. Assessment of SPLAT formulations to control Grapholita molesta (Lepidoptera: Tortricidae) in a Brazilian apple orchard. Chilean J. Agric. Res. 74: 184-190.

Beckman, T. G., J. X. Chaparro, and W. B. Sherman. 2008. 'Sharpe', a Clonal Plum Rootstock for Peach. HortScience 43: 2236-2337.

Bottger, G. T., and R. Patana. 1966. Growth, development, and survival of certain lepidoptera fed gossypol in the diet. J. Econ. Entomol. 59: 1166-1168.

Botton, M., C. J. Ariolli, and V. Colletta. 2001. Monitoramento da mariposa oriental Grapholita molesta (Busck, 1916) na cultura do pessegueiro. Embrapa Uva e Vinho/Comunicado Técnico 38: 1-4.

Botton, M., D. Nava, C. Arioli, A. Grutzmacher, and M. Garcia. 2011. Bioecologia, monitoramento e controle da mariposa-oriental na cultura do pessegueiro no Rio Grande do Sul. Circular Técnica/Embrapa Uva e Vinho 86: 11.

Cao, K., L. Wang, G. Zhu, W. C. Fang, and C. W. Chen. 2011. Isolation, characterisation and phylogenetic analysis of resistance gene analogues in a wild species of peach (Prunus kansuensis). Can. J. Plant Sci. 91: 961-970.

Castro, L.A.S. 2010. Sistema de produção de material propagativo de pessegueiro com alta sanidade. Embrapa Clima Temperado/Sistema De Produção 18: 109.

Chaves, C. C., C. A. Baronio, M. Botton, and M. S. Garcia. 2014. Efeito de inseticidas em diferentes fases de desenvolvimento de Grapholita molesta (Busck, 1916) (Lepidoptera: Tortricidae) e estruturas vegetais da macieira e do pessegueiro. Revista Brasileira De Fruticultura 36: 842-852.

Cottrell, T., T. Beckman, and D. Horton. 2011. Lesser peachtree borer (Lepidoptera: Sesiidae) oviposition on Prunus germplasm. Environ. Entomol. 40: 1465-1470. 
Cottrell, T. E., J. Fuest, and D. L. Horton. 2008. Influence of Prunus spp., peach cultivars, and bark damage on oviposition choices by the lesser peachtree borer (Lepidoptera: Sesiidae). Environ. Entomol. 37: 1508-1513.

Edwards, P. J., and S. Wratten. 1981. Ecologia das interações entre insetos e plantas.vol. 27. EPU/Editora da Universidade de Sao Paulo, São Paulo, Brazil.

Joshi, N., L. Hull, C. Myers, G. Krawczyk, and E. Rajotte. 2007. Oviposition preference of Oriental fruit moth [Grapholita molesta (Busck), Lepidoptera: tortricidae] for apple cultivars, pp. 308-309. In 16th International Plant Protection Congress, 15-18 October 20072007, Glasgow. British Crop Protection Council, Glasgow, Scotland, United Kingdom.

Joshi, N. K., E. G. Rajotte, C. T. Myers, G. Krawczyk, and L. A. Hull. 2015. Development of a susceptibility index of apple cultivars for codling moth, Cydia pomonella (L.) (Lepidoptera: Tortricidae) oviposition. Front. Plant Sci. 6: 992.

Kogan, M. 1998. Integrated pest management: historical perspectives and contemporary developments. Annu. Rev. Entomol. 43: 243-270.

Lara, F. M. 1991. Princípios de resistência de plantas a insetos. Livroceres, São Paulo, Brazil.

Maia, A.H.N., A. J. Luiz, and C. Campanhola. 2000. Statistical inference on associated fertility life table parameters using jackknife technique: computational aspects. J. Econ. Entomol. 93: 511-518.

Mayer, N., and B. Ueno. 2012. A morte-precoce do pessegueiro e suas relações com porta-enxertos. Documentos/Embrapa Clima Temperado 359: 42.

Mayer, N., B. Ueno, and L. Antunes. 2009. Seleção e clonagem de portaenxertos tolerantes à morteprecoce do pessegueiro. Embrapa Clima Temperado/Comunicado Técnico. 209: 13.

Mayer, N. A., B. Ueno, C. Fischer, and L. C. Migliorini. 2013. Propagação vegetativa de frutíferas de caroço por estacas herbáceas em escala comercial. Boletim De Pesquisa e Desenvolvimento/Embrapa Clima Temperado 195: 55.
Myers, C. T., L. A. Hull, and G. Krawczyk. 2006. Seasonal and cultivarassociated variation in oviposition preference of oriental fruit moth (Lepidoptera: Tortricidae) adults and feeding behavior of neonate larvae in apples. J. Econ. Entomol. 99: 349-358.

Myers, C. T., L. A. Hull, and G. Krawczyk. 2007. Effects of orchard host plants (apple and peach) on development of oriental fruit moth (Lepidoptera: Tortricidae). J. Econ. Entomol. 100: 421-430.

Pastori, P. L., C. J. Arioli, M. Botton, L. B. Monteiro, L. Stoltman, and A. Mafra-Neto. 2012. Integrated control of two tortricid (Lepidoptera) pests in apple orchards with sex pheromones and insecticides. Revista Colombiana De Entomología. 38: 224-230.

Salles, L. D. 1991. Grafolita (Grapholita molesta): bioecologia e controle. Documentos/Embrapa CNPFT. 42: 13.

Salles, L. D., and L. Marini. 1989. Etiologia do ataque das lagartas de Grapholita molesta (Busck, 1916)(Lepidoptera: Tortricidae) em pessegueiros. Anais Da Sociedade Entomológica Do Brasil. 2: 337-345.

SAS Institute. 2000. Statistical analysis system: getting started with the SAS learning computer program. SAS Institute, Carry, NC.

Silva, F.A.S., and C.A.V. de Azevedo. 2016. The Assistat Software Version 7.7 and its use in the analysis of experimental data. Afr. J. Agric. Res. 11: 3733-3740.

Silva, O.A. B.N.E., M. Botton, M. S. Garcia, A. Z. Bisognin, and D. E. Nava. 2010. Desenvolvimento e reprodução da mariposa-oriental em macieira e pessegueiro. Pesquisa Agropecuária Brasileira 45: 1082-1088.

Smith, C. 2005. Factors affecting the expression of plant resistance to arthropods. Plant resistance to arthropods: molecular and conventional approaches, pp. 183-217. Springer, Dordrecht, NL.

Straub, D. 2003. Susceptibility of new apple cultivars to various arthropod pests. NY Fruit Q. 11: 25-28. 